\title{
Association of weather variables with the migration phenology and body conditions of Siberian warblers
}

\author{
László Bozó*, Yury Anisimov \& Tibor Csörgő
}

L. Bozó, Department of Systematic Zoology and Ecology, Eötvös Loránd University, 1117 Budapest, Pázmány Péter sétány 1/C, Hungary. * Corresponding author's e-mail: bozolaszlo91@gmail.com

Y. Anisimov, Baikalsky State Nature Biosphere Reserve, 671220 Russia, Tankhoy, Krasnogvardeiskaya str. 34., Republic of Buryatia, Baikalskaya

T. Csörgö, Department of Anatomy, Cell- and Developmental Biology, Eötvös Loránd University, 1117 Budapest, Pázmány Péter sétány 1/C, Hungary

Received 11 November 2020, accepted 5 December 2021

Different elements of weather, such as wind speed, wind direction, precipitation and temperature are very important regulators of bird migration. Weather conditions also play role on the body condition such as body mass and the deposited fat. In this study we selected four warbler species to examine the impact of different weather variables on their

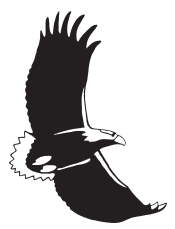
spring and autumn migration timing and their body condition in one of the most extreme weather areas of the Earth, at Lake Baikal in Siberia. We also studied the changes in body mass and fat reserves during the spring and autumn migration periods of these species. For the analyses, we used ringing data of 2471 birds from five spring and five autumn seasons during 2015-2019. According to our results, it can be stated that the weather did not have a significant association with the migration timing of the studied warblers, perhaps due to the geographical location of the study site. However, the body mass and the fat reserves of the birds increased during unsuitable weather conditions because of the increased energy requirements. Birds generally migrate with low fat reserves, which is due to the fact that this area is not an important stopover site for these species.

\section{Introduction}

Birds usually migrate in windless, anticyclonic weather conditions without precipitation or with the support of tailwinds (Alerstam 1990, Gyurácz et al. 1997, 2003, Bruderer \& Boldt 2001, Erni et al. 2002), while cloudy skies, poor visibility, strong head- or crosswinds, and warm or occluded fronts have negative effects on the migration (Åkesson 1993, Pyle et al. 1993). The most intense migration occurs in synoptic weather conditions, in the transitional phase on the western side of low-pressure systems and the eastern side of high-pressure areas, when the temperature decreases, the sky clears, the air pressure increases and the wind direction changes (Alerstam 1990). Wind speed and direction are also key regulators of migration (Cochran \& Kjos 1985, Weber \& Hedenström 2000, Pennycuick \& 
Battley 2003, Cochran \& Wikeski 2005, Bowlin \& Wikelski 2008, Shamoun-Baranes \& van Gasteren 2011, Bulte et al. 2014, Gill et al. 2014), even if the observation methods overestimate the effect of wind on the migration (Erni et al. 2002). Not only the wind but also the rain determines the end of a stopover period, and these two factors synchronize the flights of most migrants (Schaub et al. 2004). Temperature also clearly has an effect on the timing of bird migration. In spring, the local temperature on the breeding grounds affected at least the early subsets of the bird populations (Tøttrup et al. 2010). In the case of Pied Flycatcher (Ficedula hypoleuca), the progression of spring migration is strongly influenced by temperature en route (Hüppop \& Winkel 2006). As a result of global climate change, more and more migratory bird species return to their breeding grounds earlier in spring, which also indicates that temperatures - at least in spring - affect bird migration (Kullberg et al. 2015, Bozó \& Csörgő 2020).

In the present study, we examined the impact of different weather variables on bird migration in one of the most extreme weather areas of the Earth, near South Siberia. Species migrating there use the East Asian-Australasian migratory flyway, which, despite being extremely species-rich, is the least studied of the migratory systems (Yong et al. 2015, 2021). In recent years, intensive research has been conducted in the region (Bozó \& Csörgö under review), but the impact of weather on songbird migration has only been studied in the Russian Far East (Bozó et al. 2018), not yet in Siberia. We hypothesize that the migration of small songbirds is influenced by the weather, however, based on the results of a similar study in the Russian Far East (Bozó et al. 2018), these effects are less significant in spring than in autumn. We also examined how much fat the birds had during the different migration periods, and how much the weather associates with the weight and the stored fat reserves of the birds. Since unsuitable weather conditions increase the energy requirements of the birds (Richardson 1978), we hypothesized that in case of low temperature, rain or strong winds the stored fat of birds is higher than in case of calm weather conditions.In this study, we selected four species of warblers that migrate in large numbers in the study area, but differ in some of their characteristics (body size, size of distribution area, habitat, migration period): the Thick-billed Warbler (Arundinax aedon), the Yellow-browed Warbler (Phylloscopus inornatus), the Dusky Warbler (Ph. fuscatus) and the Pallas's Leaf Warbler (Ph. proregulus). We chose these four species because we wanted to find out whether closely related species are affected by the same weather factors in the same way or differently under the same conditions.

\section{Material and methods}

\subsection{Study species}

The Thick-billed Warbler (18-19 cm body length and 22-31 g weight), breeds mainly in continental lowlands, dense thickets, bushes, tall grasses, edges and clearings of forests, in gardens, along roads, near lakes and in river valleys. It breeds in South-Central Siberia east of the Sea of Japan, and in North China north to the Lake Baikal (Dyrcz 2020). Despite its extremely large distribution range with a total area of 7,180,000 $\mathrm{km}^{2}$, its population is declining (BirdLife International 2020). The Yellow-browed Warbler is a small leaf warbler (10-11 cm, 4.3-6.5 g), and breeds between 1000 and 2440 meters in a variety of broadleaf forests (Clement 2020a). The Yellow-browed Warbler has the largest distribution area of species in this study with a total area of $15,900,000 \mathrm{~km}^{2}$, and its population is stable (BirdLife International 2020). It breeds in Northern Russia from middle and upper Pechora and Ural mountains east of East Siberia, south to Northeast Altai, Northwest Mongolia, Baikal Mountains and Northeast China (Clement 2020a). The Dusky Warbler is a small (11-12 cm, 8.5-13.5 g), polytypic leaf warbler with three subspecies. It breeds in scrub and low dense vegetation areas in taiga forests along streams, sedge-swamps and reed-swamps and in floodplain meadows in marshy river valleys (Clement 2020b). The nominate Ph. f. fuscatus breeds in Central and East Siberia, Mongolia, Northeast China and in the Russian Far East (Clement 2020b). It has an extremely large distribution area with a total area of $15,600,000 \mathrm{~km}^{2}$, and its population is stable (BirdLife International 2020). The Pallas's Leaf Warbler is the smallest 
Table 1. Number of captured individuals for each species for both spring (Spr) and autumn (Aut) season. Final sample size refers to the data used for the analyses of changes in body mass and stored fat.

\begin{tabular}{|c|c|c|c|c|c|c|c|c|c|c|c|c|c|c|}
\hline \multirow[b]{2}{*}{ Species } & \multicolumn{2}{|c|}{2015} & \multicolumn{2}{|c|}{2016} & \multicolumn{2}{|c|}{2017} & \multicolumn{2}{|c|}{2018} & \multicolumn{2}{|c|}{2019} & \multicolumn{2}{|l|}{ Total } & \multicolumn{2}{|c|}{$\begin{array}{l}\text { Final } \\
\text { sample size }\end{array}$} \\
\hline & Spr & Aut & Spr & Aut & Spr & Aut & Spr & Aut & Spr & Aut & Spr & Aut & Spr & Aut \\
\hline $\begin{array}{l}\text { Thick-billed } \\
\text { Warbler }\end{array}$ & 38 & 29 & 92 & 108 & 80 & 58 & 88 & 113 & 144 & 116 & 442 & 424 & 442 & 423 \\
\hline $\begin{array}{l}\text { Dusky } \\
\text { Warbler }\end{array}$ & 37 & 41 & 64 & 68 & 56 & 68 & 70 & 41 & 80 & 76 & 307 & 294 & 294 & 285 \\
\hline $\begin{array}{l}\text { Yellow-browed } \\
\text { Warbler }\end{array}$ & 5 & 15 & 12 & 56 & 19 & 79 & 4 & 73 & 17 & 71 & 57 & 294 & 54 & 284 \\
\hline $\begin{array}{l}\text { Pallas's } \\
\text { Leaf Warbler }\end{array}$ & 6 & 52 & 12 & 139 & 9 & 156 & 15 & 104 & 12 & 148 & 54 & 599 & 53 & 585 \\
\hline
\end{tabular}

of all study species $(9-10 \mathrm{~cm}, 4.5-7.5 \mathrm{~g})$, and has the smallest distribution range with a total area of $6,680,000 \mathrm{~km}^{2}$ (BirdLife International 2020). It breeds in the taiga coniferous forest or in mixed forest with a high percentage of conifers. Its breeding range is in South-Central and Southeast Siberia from the Altai Mountains east of north Sea of Okhotsk, south to North Mongolia, Northeast China and Sakhalin (Alström et al. 2020). Its population is stable (BirdLife International 2020).

\subsection{Data collection}

Fieldwork was carried out in the buffer zone of Baikalsky State Nature Biosphere Reserve, which is on the southeast coast of Lake Baikal, southwest from the Mishikha River mouth on Pribaikalskaya flatland (51³8'37.5” N 105'31'23.9” E). The surrounding vegetation is dominated by cedar (Cedrus sp.) forests mixed with birch (Betula spp.), aspen (Populus spp.), fir (Abies spp.), interspersed with small willow (Salix spp.) bushes and grass meadows. The birds were captured with mist-nets with a total length of 210 metres. Mist-nets were checked every 60 minutes from sunrise to sunset, and every 30 minutes during inclement weather. We used data from five spring (from 15 May to 20 June) and five autumn (from 1 August to 25 October) seasons during 2015-2019. Rings were supplied by the Moscow Ringing Centre. Species identification followed Svensson (1992) and Demongin (2016). In this study, we only used the data from transient individuals, excluding
Table 2. Daily percentage distribution of different wind speed and wind direction categories.

\begin{tabular}{lllll}
\hline & \multicolumn{2}{l}{ Wind speed } & \multicolumn{2}{l}{ Wind direction } \\
\cline { 2 - 5 } Day & Spring & Autumn & Spring & Autumn \\
\hline 1 & 25 & 30.5 & 0.6 & 4.4 \\
2 & 36.6 & 33.2 & 0.6 & 3.7 \\
3 & 31.3 & 22.3 & 5.7 & 5.9 \\
4 & 7.1 & 12.7 & 1.3 & 5.9 \\
5 & 0 & 1.3 & 1.9 & 6.5 \\
6 & 0 & 0 & 9.4 & 9 \\
7 & 0 & 0 & 21.4 & 4.4 \\
8 & 0 & 0 & 13.8 & 8.1 \\
9 & 0 & 0 & 1.9 & 13.7 \\
10 & 0 & 0 & 8.8 & 18.7 \\
11 & 0 & 0 & 5 & 9.3 \\
12 & 0 & 0 & 5 & 4.4 \\
13 & - & - & 10.1 & 0 \\
14 & - & - & 6.3 & 4.4 \\
15 & - & - & 3.8 & 1.6 \\
16 & - & - & 4.4 & 0 \\
\hline
\end{tabular}

possible local breeders (birds with brood patch or long-term recaptures). In addition, we only included data of first captures and excluded all recaptures. From the recorded biometric data, only the body mass and fat score were used for this study. Body mass was measured to the nearest $0.1 \mathrm{~g}$, while fat scores followed Kaiser (1993) 
on a scale of 0 to 8 . Because of the small sample size, fat scores 4-8 were merged into category 3+, similarly to other studies (e. g. Brown et al. 2002, Turcotte \& Desrochers 2008). Data analysis was based on 2471 individuals of four species (Thickbilled Warbler, Dusky Warbler, Yellow-browed Warbler and Pallas's Leaf Warbler) (Table 1).

The following weather variables were selected to analyse the association of weather with bird migration timing and the body conditions of the individuals: minimum daily temperature, maximum daily temperature, daily average temperature $\left({ }^{\circ} \mathrm{C}\right)$, precipitation $(\mathrm{mm})$, daily average wind speed (Beaufort scale 0-12) and wind direction. Since the temperature variables are highly correlated with each other in both seasons $(R>0.7, p<0.001$ in all cases), only the daily average temperature values were used in the analyses. For the statistical analyses, the wind direction was categorized on a scale of 1-16, at which the tailwind received the highest score in both spring and autumn seasons (in spring the southern, in autumn the northern winds, circular coordinates). In order to illustrate the variability of the wind direction and wind speed data, the percentage of daily different wind speed and wind direction categories is given in Table 2. We used weather data from the nearest meteorological station located in Babushkin. All data were gathered from the website of National Centers for Environmental Information.

Multiple regressions were used to evaluate the impact of weather on the number of birds trapped per day and on the body conditions (deposited fat and body weight) of each trapped individuals. Given that many statistical tests have been carried out, we have taken type 1 errors into account and therefore focus on the biologically strongest effects when evaluating the results. Regressions were used for each species for both spring and autumn season.

According to Berthold (1973), we examined changes in body mass and stored fat over 10-day

Table 3. Results of the multiple regressions regarding to the association of different weather variables with the number of captured individuals. Significant $p$-values are in bold.

\begin{tabular}{|c|c|c|c|c|c|c|c|c|c|}
\hline \multirow[b]{2}{*}{ Species } & \multirow[b]{2}{*}{ Variable } & \multicolumn{4}{|l|}{ Spring } & \multicolumn{4}{|l|}{ Autumn } \\
\hline & & Coefficient & $t$ & $p$ & $\mathrm{R}^{2}$ & Coefficient & $t$ & $p$ & $\mathrm{R}^{2}$ \\
\hline \multirow{4}{*}{$\begin{array}{l}\text { Thick-billed } \\
\text { Warbler }\end{array}$} & Temperature & 0.089 & 0.74 & 0.463 & 0.0057 & 0.003 & 0.03 & 0.977 & 0.0026 \\
\hline & Wind speed & -0.075 & -0.61 & 0.541 & 0.0044 & -0.045 & -0.67 & 0.506 & 0.0082 \\
\hline & Wind direction & -0.086 & -0.63 & 0.531 & 0.0002 & -0.061 & -0.58 & 0.563 & 0.0041 \\
\hline & Precipitation & -0.041 & -0.11 & 0.910 & 0.0007 & -0.125 & -0.96 & 0.338 & 0.0070 \\
\hline \multirow{4}{*}{$\begin{array}{l}\text { Dusky } \\
\text { Warbler }\end{array}$} & Temperature & 0.045 & 1.00 & 0.316 & 0.0059 & 0.017 & 0.84 & 0.401 & 0.0138 \\
\hline & Wind speed & -0.013 & -0.28 & 0.778 & 0.0011 & -0.042 & -2.30 & 0.022 & 0.0264 \\
\hline & Wind direction & -0.039 & -0.78 & 0.439 & 0.0009 & 0.021 & 0.70 & 0.486 & 0.0018 \\
\hline & Precipitation & 0.066 & 0.50 & 0.619 & 0.0006 & 0.008 & 0.20 & 0.843 & 0.0006 \\
\hline \multirow{4}{*}{$\begin{array}{l}\text { Yellow- } \\
\text { browed } \\
\text { Warbler }\end{array}$} & Temperature & -0.055 & -2.93 & 0.004 & 0.0292 & -0.011 & -0.48 & 0.629 & 0.0001 \\
\hline & Wind speed & -0.026 & -1.36 & 0.177 & 0.0003 & -0.023 & -1.01 & 0.311 & 0.0016 \\
\hline & Wind direction & -0.005 & -0.22 & 0.827 & 0.0006 & 0.019 & 0.48 & 0.630 & 0.0001 \\
\hline & Precipitation & -0.072 & -1.29 & 0.198 & 0.0105 & 0.007 & 0.12 & 0.901 & 0.0001 \\
\hline \multirow{4}{*}{$\begin{array}{l}\text { Pallas's } \\
\text { Leaf } \\
\text { Warbler }\end{array}$} & Temperature & -0.011 & -0.75 & 0.456 & 0.0000 & 0.022 & 0.43 & 0.671 & 0.0018 \\
\hline & Wind speed & -0.028 & -1.92 & 0.057 & 0.0096 & -0.059 & -1.09 & 0.276 & 0.0055 \\
\hline & Wind direction & -0.020 & -1.19 & 0.236 & 0.0015 & 0.070 & 0.80 & 0.423 & 0.0000 \\
\hline & Precipitation & 0.012 & 0.27 & 0.784 & 0.0003 & -0.126 & -0.94 & 0.350 & 0.0043 \\
\hline
\end{tabular}


periods. Differences among body mass change in subsequent 10-day periods were tested using the Kruskal-Wallis-test. Periods with fewer than 10 individuals per species were excluded from our analysis (Yosef \& Chernetsov 2004, Bozó et al. 2020a). All statistical analyses were carried out in Past 3.14 (Hammer et al. 2001), while figures were created by Microsoft Excel 2013.

\section{Results}

\subsection{Associations between different weather variables and numbers of captured birds}

In spring, the lower the temperature, the higher the number of Yellow-browed Warblers caught in the nets (Table 3). In autumn, the stronger the wind, the less Dusky Warblers caught in the nets. (Table 3).

\subsection{Fat accumulation and body weight}

In spring, in the case of Dusky Warblers, and Pallas's Leaf Warblers, body weight decreased significantly over time (Table 4, Fig. 1). In autumn, for Yellow-browed Warbler and Pallas's Leaf Warbler, both the amount of stored fat and body weight increased over time (Table 4, Fig. 2).

It is the characteristic of all species that they migrate with very low fat reserves both in spring and autumn. The only exception is the Thickbilled Warbler, for which body fat values of 4 or more were measured in nearly $20 \%$ of the birds caught in autumn (Fig. 3, Fig. 4).

\subsection{Associations between weather variables and the body mass and fat reserves}

There were both similarities and differences between spring and autumn in relation to the association of different weather variables with the weight and fat reserves of the birds. We detected significant negative relationships between body condition and temperature, and positive relationship between body condition, wind speed and tailwinds, but these were not uniformly detected in all species and seasons (Table 5).
Table 4. Results of Kruskal-Wallis-test regarding to the changes in body mass and fat over time. Significant $p$-values are in bold.

\begin{tabular}{|c|c|c|c|c|}
\hline Species & Season & Variable & $H$ & $p$ \\
\hline \multirow{4}{*}{$\begin{array}{l}\text { Thick- } \\
\text { billed } \\
\text { Warbler }\end{array}$} & \multirow{2}{*}{ Spring } & Body mass & 1.99 & 0.369 \\
\hline & & Fat & 3.12 & 0.183 \\
\hline & \multirow{2}{*}{ Autumn } & Body mass & 2.26 & 0.520 \\
\hline & & Fat & 3.72 & 0.231 \\
\hline \multirow{4}{*}{$\begin{array}{l}\text { Dusky } \\
\text { Warbler }\end{array}$} & \multirow{2}{*}{ Spring } & Body mass & 29.70 & $<0.001$ \\
\hline & & Fat & 0.12 & 0.934 \\
\hline & \multirow{2}{*}{ Autumn } & Body mass & 12.95 & 0.024 \\
\hline & & Fat & 96.32 & $<0.001$ \\
\hline \multirow{4}{*}{$\begin{array}{l}\text { Yellow- } \\
\text { browed } \\
\text { Warbler }\end{array}$} & \multirow{2}{*}{ Spring } & Body mass & 0.03 & 0.852 \\
\hline & & Fat & 0.31 & 0.562 \\
\hline & \multirow{2}{*}{ Autumn } & Body mass & 36.75 & $<0.001$ \\
\hline & & Fat & 28.57 & $<0.001$ \\
\hline \multirow{4}{*}{$\begin{array}{l}\text { Pallas's } \\
\text { Leaf } \\
\text { Warbler }\end{array}$} & \multirow{2}{*}{ Spring } & Body mass & 11.79 & 0.003 \\
\hline & & Fat & 8.49 & 0.010 \\
\hline & \multirow{2}{*}{ Autumn } & Body mass & 35.81 & $<0.001$ \\
\hline & & Fat & 39.46 & $<0.001$ \\
\hline
\end{tabular}

\section{Discussion}

According to our results, the various elements of the weather were generally not associated with numbers of birds captured. Only the strength of the wind was associated with migration of the Dusky Warblers: the stronger the wind, the fewer the birds were caught in the nets. However, temperature, wind speed and direction influenced the weight and fat reserves of the birds.

Birds during their migration achieve the fastest, the cheapest or the safest possible migration (optimal migration strategies, reviewed in Alerstam \& Hedenström 1998), in which the strength of the wind and its direction play an important role (Richardson 1978). Wind in the right direction and strength contributes to optimal migration, as it allows birds to travel longer distances with a given amount of stored nutrients (Alerstam 1978, Richardson 1978). In strong winds, small birds are not able to compensate for winds in the opposite direction to migration (Elkins 1988). Therefore, in this case, they are 
A
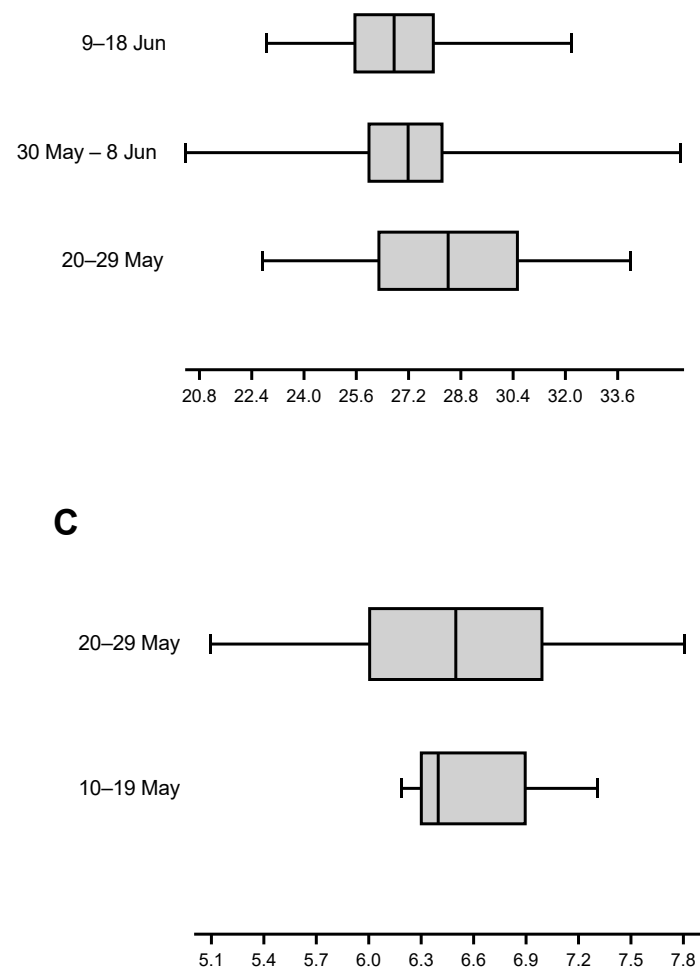

B
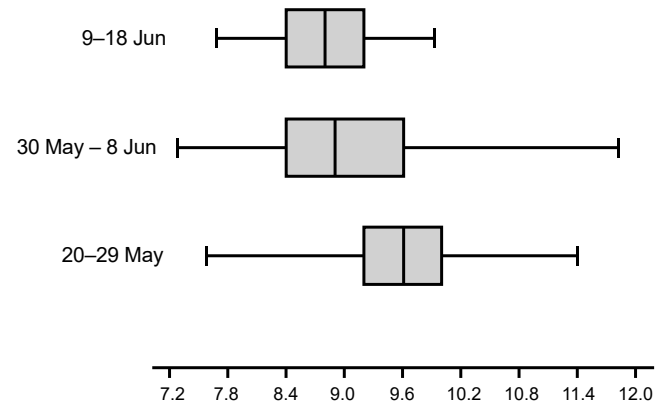

D
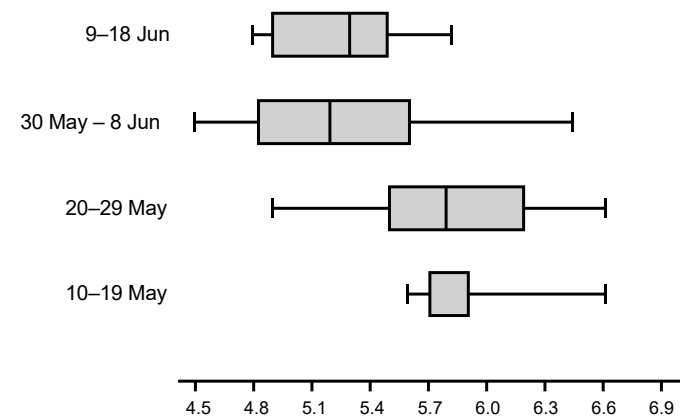

Fig. 1. Changes in body mass (X-axis) during subsequent decades in spring for Thick-billed Warbler (A), Dusky Warbler (B), Yellow-browed Warbler (C) and Pallas's Leaf Warbler (D).

more likely to die or move to suboptimal areas, up to thousands of kilometers away, as in the case of appearances in Europe of several species studied in this study (Baker 1977, Howey \& Bell 1985, Baker \& Catley 1987). Taking the energy and mortality minimization strategies into account, it is understandable that the studied species migrate in significantly smaller numbers in strong winds than in windless weather. Bozó et al. (2018) obtained similar results for the same species in the Muraviovka Park, an important stopover site located in the Russian Far East, 1,500 kilometers east of Lake Baikal. In the case of the Thickbilled Warbler, however, there was no correlation between wind strength and the number of birds, perhaps due to the fact that of the four species studied, it uses the closest, densest habitats nearest to the ground (del Hoyo et al. 2006), where the effect of the wind is less pronounced than in the canopy. This is true even if the nets are the same height and do not cover the canopy. Regarding the wind strength, it should be mentioned that in strong winds nets are often incapable of catching because the pockets are tightened and the birds do not get caught in the net. Capture probability varies by species and movement height (Lövei et al. 2001). Smaller species have a superior manoeuvring capability and thus avoid capture with a higher probability. For this reason, it is conceivable that the probability of catching decreases due to strong winds, so that the wind strength distorts the results in this form.

Most studies have found a correlation between tailwinds and the number of migratory birds (Emlen 1975, Bloch \& Bruderer 1982, Gauthreaux 1982, 1991, Alerstam 1990, Richardson 1990, Åkesson \& Hedenström 2000, Bozó et al. 2018). Some studies consider the tailwind as a criterion for successful migration in certain cases (Piersma \& Jukema 1990, Butler 
A

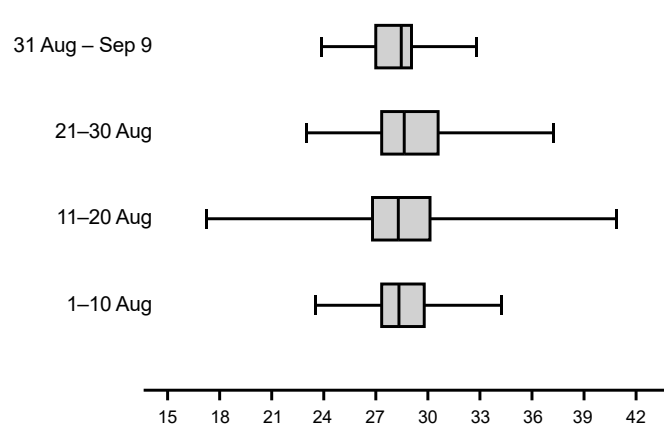

C

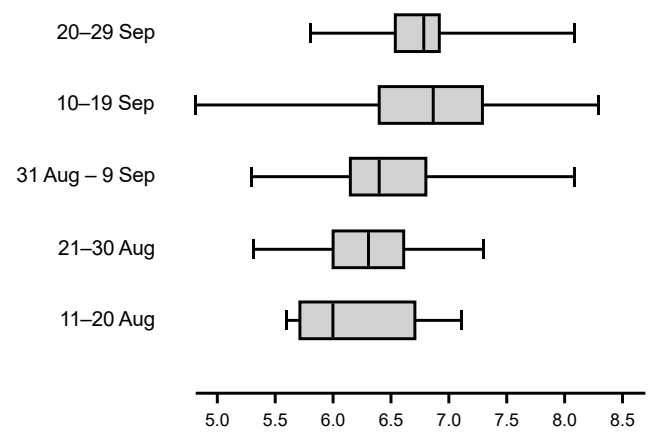

B

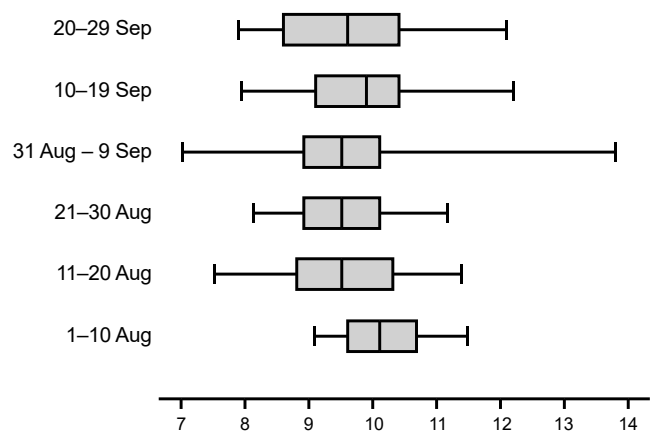

D

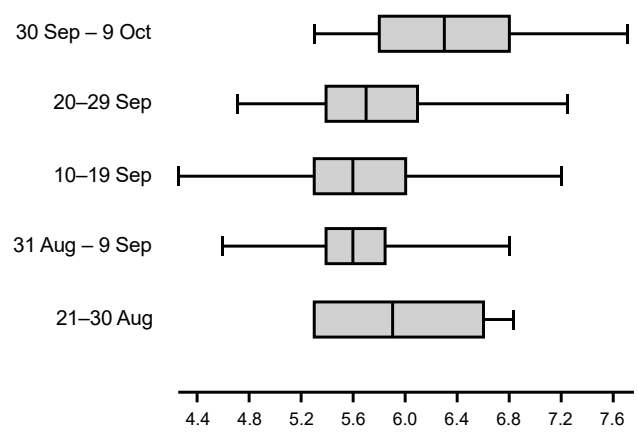

Fig. 2. Changes in body mass (x-axis) during subsequent decades in autumn for Thick-billed Warbler (A), Dusky Warbler (B), Yellow-browed Warbler (C) and Pallas's Leaf Warbler (D).

et al. 1997). Others, such as Fransson (1998) found no correlation between the tailwind and the departure of birds from the stopover site in the case of the Common Whitethroat (Sylvia communis). Bozó et al. (2018) found a difference in the association of wind direction with migration in spring and autumn, since tailwinds in autumn and crosswinds in spring proved to be decisive for several Siberian Phylloscopus species. The study of Erni et al. (2002) shows that birds distinguish between favourable and unfavourable weather conditions, however, they observed that birds migrated not only in the case of opposing winds but also in the case of weak crosswinds. This may be due to the fact that western winds predominate in central Europe, so birds generally do not encounter supporting winds. The same may be the case at Lake Baikal, where mainly eastern winds predominate (Lutgens \& Tarbuck 2001), so birds cannot use support winds in spring and autumn, so it is understandable that wind direction has no effect on their migration.

Bird migration is also significantly associated with precipitation: birds migrate mainly in rainless weather, while prolonged rainfall slows down the migration (Richardson 1978, Alerstam 1990). In central Europe, relative migration intensity decreased as rain duration increased (Erni et al. 2002), and in the Russian Far East, Bozó et al. (2018) also found that migration was significantly lower on rainy days. Nevertheless, no correlation was found between the amount of precipitation and the migration (number of captured birds) of the studied species in this study. According to our own observations, certain species (e.g. buntings, finches, thrushes) migrated in huge (ten thousand) masses, concentrated in some areas on some days, while at other times they may have been completely absent. In contrast, this was not the case for the 
leaf warblers as they were caught in roughly the same amount during the whole migration period, including rainy days. As Phylloscopus species migrate from tree to tree during the day over very short distances, their movement is unlikely to be affected to the same extent by rain as species that fly longer distances.

Previous studies have shown that bird migration generally intensifies in the spring as temperatures rise, while in autumn it tends to intensify as temperatures decline (reviewed by Richardson 1978). According to the results of similar studies on Phylloscopus species in the Muraviovka Park, temperature proved to be the most important weather variable on the migration (Bozó et al. 2018): in the case of Yellow-browed Warblers and Dusky Warblers, most individuals were caught in the nets at higher temperatures in both spring and autumn, while Pallas's Leaf Warblers had the same situation in the spring, but most birds were caught in rising temperature. In the present study, a negative correlation between temperature and the number of birds in spring was only found in the case of Yellow-browed Warblers, which is contrary to the results of most studies. However, e.g. Richardson (1978) found that eastward migration in the northern Yukon tends to occur with low temperature, because in that area following westerly winds tend to be cold. For this reason, it is conceivable that we obtained a negative correlation in spring because the dominant eastern winds are typically cold and birds migrate regardless of its temperature. It should be noted, that given the low sample size and multiple testing, this association needs to be carefully considered.

The species studied migrated with very low fat reserves in both spring and autumn. This may be due to the fact that this area is not an

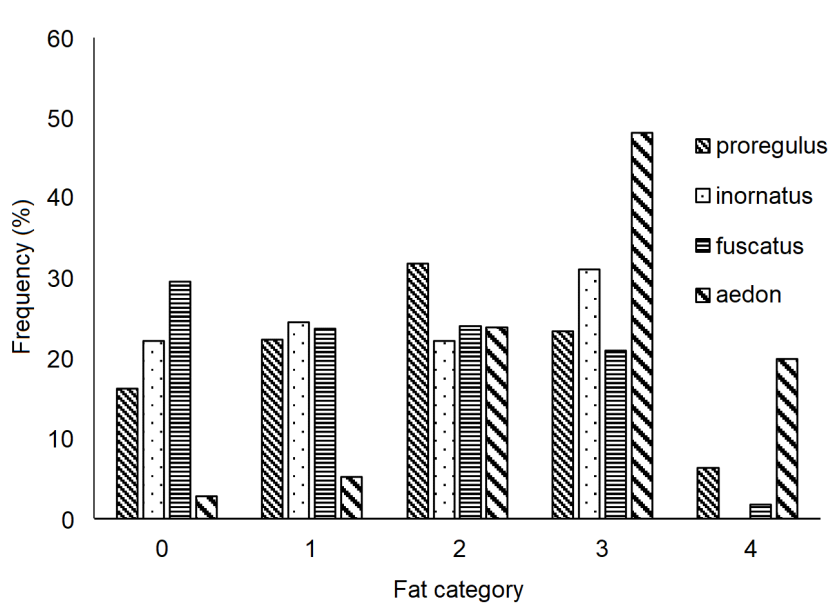

Fig. 4. Frequencies of different fat categories of the study species in autumn.

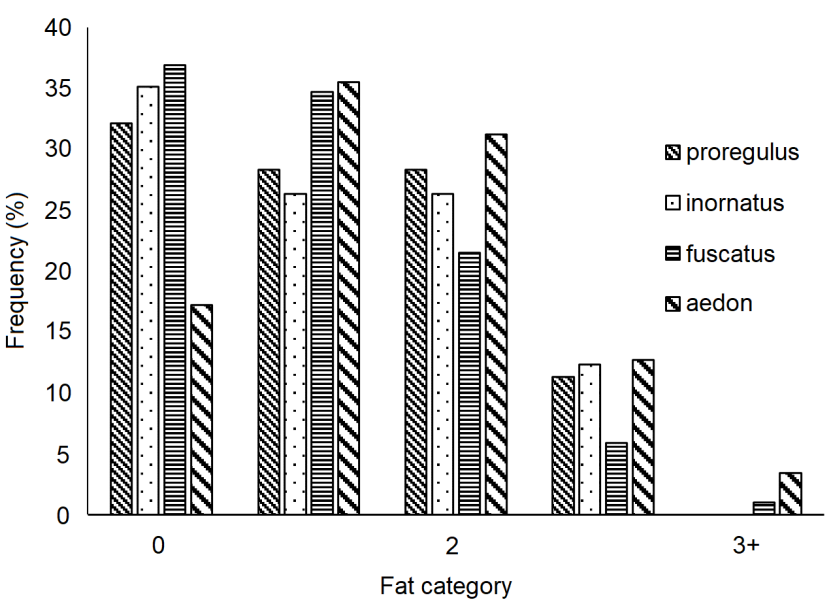

Fig. 3. Frequencies of different fat categories of the study species in spring. important stopover site, birds just migrate through and only replenish their energy stores later. This is also confirmed by the fact that there are no within-season recaptures, the birds quickly moved out of the area. There are no habitat patches for the Thick-billed Warblers where they could stop over for feeding for a longer period, but the taiga forest and its edge would be an optimal habitat for leaf warblers. Yellow-browed Warblers migrating in the Muraviovka Park also had low fat reserves and spent a short time in the area (Bozó et al. 
Table 5. Results of the multiple regressions regarding to the association of different weather variables (temperature, wind speed, wind direction and precipitation) with the weight and stored fat of the trapped birds. Significant $p$-values are in bold.

\begin{tabular}{|c|c|c|c|c|c|c|c|c|c|c|}
\hline \multirow[b]{2}{*}{ Species } & \multirow[b]{2}{*}{ Constant } & \multirow[b]{2}{*}{ Variable } & \multicolumn{4}{|l|}{ Spring } & \multicolumn{4}{|c|}{ Autumn } \\
\hline & & & Coef. & $t$ & $p$ & $R^{2}$ & Coef. & $t$ & $p$ & $R^{2}$ \\
\hline \multirow{8}{*}{$\begin{array}{l}\text { Thick- } \\
\text { billed } \\
\text { Warbler }\end{array}$} & \multirow{4}{*}{ Weight } & Temp. & -0.083 & -1.91 & 0.057 & 0.0110 & 0.002 & 0.024 & 0.981 & 0.0023 \\
\hline & & Wind s. & 0.086 & 2.90 & 0.004 & 0.0099 & -0.015 & -0.404 & 0.686 & 0.0006 \\
\hline & & Wind d. & -0.010 & -0.46 & 0.646 & 0.0040 & 0.121 & 2.647 & 0.008 & 0.0184 \\
\hline & & Prec. & -0.289 & -3.54 & 0.000 & 0.0089 & 0.020 & 0.294 & 0.769 & 0.0001 \\
\hline & \multirow{4}{*}{ Fat } & Temp. & 0.027 & 1.12 & 0.264 & 0.0062 & -0.052 & -2.300 & 0.022 & 0.0415 \\
\hline & & Wind s. & 0.028 & 1.67 & 0.096 & 0.0015 & 0.028 & 2.250 & 0.025 & 0.0516 \\
\hline & & Wind d. & 0.029 & 2.33 & 0.020 & 0.0155 & 0.022 & 1.422 & 0.156 & 0.0237 \\
\hline & & Prec. & -0.059 & -1.29 & 0.199 & 0.0013 & 0.056 & 2.352 & 0.019 & 0.0211 \\
\hline \multirow{8}{*}{$\begin{array}{l}\text { Dusky } \\
\text { Warbler }\end{array}$} & \multirow{4}{*}{ Weight } & Temp. & -0.038 & -2.17 & 0.031 & 0.0226 & 0.002 & 0.117 & 0.907 & 0.0058 \\
\hline & & Wind s. & 0.013 & 0.96 & 0.340 & 0.0100 & 0.038 & 2.308 & 0.022 & 0.0249 \\
\hline & & Wind d. & 0.013 & 0.91 & 0.364 & 0.0001 & -0.012 & -0.701 & 0.484 & 0.0058 \\
\hline & & Prec. & -0.031 & -0.84 & 0.402 & 0.0001 & -0.014 & -0.320 & 0.749 & 0.0013 \\
\hline & \multirow{4}{*}{ Fat } & Temp. & 0.000 & 0.09 & 0.927 & 0.0001 & 0.000 & -1.171 & 0.243 & 0.0053 \\
\hline & & Wind s. & 0.013 & 0.93 & 0.355 & 0.0027 & 0.074 & 4.620 & 0.000 & 0.0787 \\
\hline & & Wind d. & -0.002 & -0.09 & 0.927 & 0.0000 & -0.003 & -0.142 & 0.887 & 0.0088 \\
\hline & & Prec. & -0.043 & -1.26 & 0.209 & 0.0055 & 0.048 & 1.230 & 0.220 & 0.0076 \\
\hline \multirow{8}{*}{$\begin{array}{l}\text { Yellow- } \\
\text { browed } \\
\text { Warbler }\end{array}$} & \multirow{4}{*}{ Weight } & Temp. & 0.034 & 1.32 & 0.194 & 0.0170 & -0.046 & -4.510 & 0.000 & 0.1200 \\
\hline & & Wind s. & 0.025 & 1.03 & 0.306 & 0.0008 & 0.020 & 2.645 & 0.009 & 0.0826 \\
\hline & & Wind d. & 0.002 & 0.09 & 0.930 & 0.0003 & -0.007 & -0.536 & 0.592 & 0.0108 \\
\hline & & Prec. & -0.251 & -1.40 & 0.166 & 0.0140 & -0.018 & -1.081 & 0.281 & 0.0002 \\
\hline & \multirow{4}{*}{ Fat } & Temp. & 0.045 & 1.04 & 0.305 & 0.0137 & -0.100 & -5.048 & 0.000 & 0.1258 \\
\hline & & Wind s. & 0.067 & 1.63 & 0.109 & 0.0393 & 0.039 & 2.744 & 0.006 & 0.0644 \\
\hline & & Wind $\mathrm{d}$. & 0.058 & 1.28 & 0.207 & 0.0107 & -0.062 & -2.443 & 0.015 & 0.0001 \\
\hline & & Prec. & 0.042 & 0.14 & 0.891 & 0.0277 & -0.024 & -0.755 & 0.451 & 0.0008 \\
\hline \multirow{8}{*}{$\begin{array}{l}\text { Pallas's } \\
\text { Leaf } \\
\text { Warbler }\end{array}$} & \multirow{4}{*}{ Weight } & Temp. & -0.070 & -3.07 & 0.004 & 0.1800 & -0.045 & -6.945 & 0.000 & 0.0644 \\
\hline & & Wind s. & -0.027 & -1.69 & 0.098 & 0.0181 & -0.010 & -1.790 & 0.074 & 0.0001 \\
\hline & & Wind $\mathrm{d}$. & -0.007 & -0.29 & 0.776 & 0.0265 & -0.011 & -1.520 & 0.129 & 0.0016 \\
\hline & & Prec. & 0.008 & 0.11 & 0.911 & 0.0413 & -0.017 & -1.068 & 0.286 & 0.0012 \\
\hline & \multirow{4}{*}{ Fat } & Temp. & 0.052 & 1.16 & 0.252 & 0.0095 & -0.103 & -7.903 & 0.000 & 0.0970 \\
\hline & & Wind s. & 0.118 & 3.64 & 0.001 & 0.1553 & -0.017 & -1.445 & 0.149 & 0.0050 \\
\hline & & Wind $\mathrm{d}$. & 0.103 & 2.25 & 0.029 & 0.0582 & -0.019 & -1.302 & 0.194 & 0.0000 \\
\hline & & Prec. & -0.182 & -1.36 & 0.179 & 0.0017 & 0.090 & 2.812 & 0.005 & 0.0160 \\
\hline
\end{tabular}


2020a). Among the European species, Common Chiffchaff (Ph. collybita) uses the same strategies, which involves migrating shorter distances with low fat reserves (Ścisłowska \& Busse 2005, Gyurácz \& Csörgö 2009). Within the autumn season Yellow-browed Warblers and Pallas's Leaf Warblers increased body weight and fat reserves, while in spring, increasing fat reserves were detected only for Pallas's Leaf Warblers. Both Pallas's Leaf Warblers and Dusky Warblers decreased body weight in the spring. Autumn body weight and fat gain may be due to the fact that individuals migrating at different times come from different latitudes, so the location of stopover sites may differ. At the same time, it is also inconceivable that later migrants will be forced to migrate with larger energy stores due to more unfavourable weather conditions in order to survive colder, sometimes wetter periods. In spring, there were already species-level differences, probably due to different feeding strategies (Price 1991, Forstmeier et al. 2001, Katti \& Price 2003, Batova 2011), nesting seasons and habitats (Glutz von Blotzheim \& Bauer 1991, del Hoyo et al. 2006).

Temperature correlated negatively with body mass and fat score in Yellow-browed Warblers and Pallas's Leaf Warblers, and most strongly in the autumn. This is due to the fact that in general, low temperature increase the energy requirements of the birds (Richardson 1978). In females of White-crowned Sparrows (Zonotrichia leucophrys gambelii) long days and low temperatures increased body mass and fat reserves. In contrast, not temperature but photostimulation affected the body mass and fat reserves of males (Wingfield et al. 2003). In case of Great Tits, residual evening weights were higher during the period of unpredictable temperatures. At the end of the period with unpredictable temperatures, more weight was gained on cold than on warm days (Bednekoff et al. 1994).

During stronger winds (especially in Yellowbrowed Warblers and Dusky Warblers in autumn, and Thick-billed Warblers and Pallas's Leaf Warblers in spring) and tailwinds (especially in Thick-billed Warblers in autumn) birds also increased their body mass and fat reserves. Birds need less energy under supporting winds the same distance to cover (Tucker 1974, Alerstam
1976). For species crossing large barriers along their migratory journey, sufficient fat reserves and tailwinds are essential (Berger \& Hart 1974, Tucker 1974). In addition, especially in spring and in case of species breeding in northern latitudes, there is a great importance of the high fat reserves, since these species often arrive to the breeding grounds very early when the food availibility is poor (Ryder 1971, Irving 2012). In addition, strong winds increase heat loss, therefore the high fat reserves are essential (Richardson 1978). Important to note, however, that all the study species are insectivorous (del Hoyo et al. 2006), therefore they would not be able to prey as much insects as they need in rainy days when insect availability is lower. This is likely the reason we observed more fat in Thick-billed Warblers and Pallas's Leaf Warblers on rainy days.

There were also intraspecific differences between seasons, which are likely explained by with different environmental and meteorological conditions and feeding opportunities for different species, and use different migratory strategies. Sample sizes varied between autumn and spring which may also contribute to such differences. A possible response to avoid these difficulties is the loop migration, when birds use different migration routes in spring and in autumn (Thorup et al. 2017, Tøttrup et al. 2017). Loop migration was studied in some Siberian Passerines, included leaf warblers, but the results showed that these species most likely use the same routes in different seasons (Bozó et al. 2020b). The reason for this is that the East Asian-Australasian migratory flyway provides continuous refueling opportunities without extreme barriers (Yong et al. 2015). However, as we noted before, these stopover sites may provide different feeding opportunities by seasons, and the birds need to change more or less their migration timing, or the responses to the different weather conditions may also be different between spring and autumn. Given that for some species we worked with a lower sample size than for others, further studies are needed to confirm the species-specific results, yet many of our results are in good agreement with those of similar studies in other migration systems. 


\section{Sääolosuhteiden vaikutus kerttujen muuttoon ja kuntoon Siperiassa}

Sääolosuhteet, kuten tuulen nopeus ja -suunta, sademäärä ja lämpötila säätelevät lintujen muuttoa. Sääolosuhteet vaikuttavat myös lintujen kuntoon, kuten painoon ja rasvavaraston määrään. Tutkimuksessa selvitimme sääolosuhteiden vaikutusta neljän kerttulajin muuton ajoittumiseen ja kuntoon sekä kevät- että syysmuutolla. Tutkimme myös painon ja rasvan muutoksia kevät- ja syysmuuton aikana. Tutkimusalueena oli Baikaljärven ympäristö Venäjällä, jossa sääolosuhteet ovat hyvin ankarat. Analysoimme aineistoa 2471 linnusta vuosina 2015-2019. Sääoloilla ei näyttänyt olevan vaikutusta muuton ajoittumiseen (lintumääriin). Lintujen paino ja rasvavarastot lisääntyivät huonon sään aikana johtuen suurentuneesta energiantarpeesta. Alueella muuttavien lintujen rasvavarastot olivat suhteellisen vähäiset, mikä voi johtua siitä, että alue ei ole tärkeä pysähtymispaikka.

Acknowledgements. The authors wish to thank the staff of Baikal Bird Ringing Station and all volunteers involved in the fieldwork. LB's fieldwork was supported by the Campus Mundi Short Term Research Scholarship (CMSMR/293048/2018). We would like to thank Nikolett Olajos for improving the language of the manuscript. We are also grateful for the helpful comments on the manuscript of an anonymous reviewer.

\section{References}

Åkesson, S. 1993. Coastal migration and wind drift compensation in nocturnal passerine migrants. - Ornis Scandinavica 24: 87-94.

Åkesson, S. \& Hedenström, A. 2000. Wind selectivity of migratory flight departures in birds. - Behavioral Ecology and Sociobiology 47(3): 140-144.

Alerstam, T. 1976. Nocturnal migration of thrushes (Turdus spp.) in southern Sweden. - Oikos 27(3): 457-475.

Alerstam, T. 1978. Reoriented bird migration in coastal areas: dispersal to suitable resting grounds? - Oikos 30(2): 405-408.

Alerstam, T. 1990. Bird migration. — Cambridge University Press, Cambridge.

Alerstam, T. \& Hedenström, A. 1998. The development of bird migration theory. - Journal of Avian Biology 103(2): 343-369.

Alström, P., Clement, P. \& Kirwan, G.M. 2020. Pallas's Leaf Warbler (Phylloscopus proregulus), version 1.0. — In
Birds of the World (eds. J. del Hoyo, Elliott, A., Sargatal, J., Christie, D.E. \& de Juana, E.). Cornell Lab of Ornithology, Ithaca, NY, USA.

Baker, K. 1977. Westward vagrancy of Siberian Passerines in autumn 1975. — Bird Study 24(4): 232-242.

Baker, K. \& Catley, G.P. 1987. Yellow-browed Warblers in Britain and Ireland, 1968-85. — British Birds 80(3): 93-109.

Batova, O.N. 2011. Selection of foraging tactics in leaf warblers (Phylloscopus). — Biology Bulletin 38(3): 259-265.

Bednekoff, P.A., Biebach, H. \& Krebs, J. 1994. Great tit fat reserves under unpredictable temperatures. - Journal of Avian Biology 25(2): 156-160.

Berger, M. \& Hart, J.S. 1974. Physiology and energetics of flight. - Avian Biology 4: 415-477.

BirdLife International 2020. IUCN Red List for birds. Downloaded from http://www.birdlife.org on 10/07/2020.

Bloch, R. \& Bruderer, B. 1982. The air speed of migrating birds and its relationship to the wind. - Behavioral Ecology and Sociobiology 11(1): 19-24.

Bowlin, M.S. \& Wikelski, M. 2008. Pointed wings, low wingloading and calm air reduce migratory flight costs in songbirds. — PLoS ONE 3:e2154.

Bozó, L., Csörgő, T. \& Heim, W. 2018. Weather conditions affect spring and autumn migration of Siberian leaf warblers. - Avian Research 9(1): 33.

Bozó, L. \& Csörgö, T. 2020. Changes in spring arrival dates of Central European bird species over the past 100 years. - Acta Zoologica Academiae Scientiarum Hungaricae 66(3). 283-298.

Bozó, L., Csörgö, T. \& Heim, W. 2020a. Stopover duration and body mass change of two Siberian songbird species at a refuelling site in the Russian Far East. Ornithological Science 19(2): 1-8.

Bozó, L., Heim, W., Anisimov, Y. \& Csörgő, T. 2020 b. Seasonal morphological differences indicate possible loop migration in two Siberian passerines. - Forktail 35: $10-17$.

Bozó, L. \& Csörgő, T. (under review). Migration of North Asian Passerines. - Amurian Zoological Journal.

Brown, D. R., Strong, C. M. \& Stouffer, P. C. 2002. Demographic effects of habitat selection by Hermit Thrushes wintering in a pine plantation landscape. The Journal of Wildlife Management 66(2): 407-416.

Bruderer, B. \& Boldt, A. 2001. Flight characteristics of birds: I. Radar measurements of speeds. - Ibis 143(2): 178-204.

Bulte, M., McLaren. J.D., Bairlein, F., Bouten, W., Schmaljohann, H. \& Shamoun-Baranes, J. 2014. Can Wheatears weather the Atlantic? Modeling nonstop trans-Atlantic flights of a small migratory songbird. Auk 131(3): 363-370.

Butler, R.W., Williams, T.D., Warnock, N. \& Bishop, M.A. 1997. Wind assistance: a requirement for migration of shorebirds? - Auk 114(3): 456-466. 
Clement, P. 2020a. Yellow-browed Warbler (Phylloscopus inornatus), version 1.0. - In Birds of the World (eds. del Hoyo, J., Elliott, A., Sargatal, J., Christie, D.E. \& de Juana, E.). Cornell Lab of Ornithology, Ithaca, NY, USA.

Clement, P. 2020b. Dusky Warbler (Phylloscopus fuscatus), version 1.0. - In Birds of the World (eds. del Hoyo, J., Elliott, A., Sargatal, J., Christie, D.E. \& de Juana, E.). Cornell Lab of Ornithology, Ithaca, NY, USA.

Cochran, W.W. \& Kjos, C.G. 1985. Wind drift and migration of thrushes: a telemetry study. - Illinois Natural History Survey Bulletin 33: 297-330.

Cochran, W.W. \& Wikeski, M. 2005. Individual migratory tactics of New World Catharus thrushes: current knowledge and future tracking options from space. In Birds of two worlds: the ecology and evolution of migratory birds (ed. Greenberg, R. \& Marra, P.P.): 274 289. Johns Hopkins University Press, Baltimore.

del Hoyo, J., Elliott, A. \& Christie, D.A. 2006. Handbook of the Birds of the World. Vol. 11. - Lynx Edicions, Barcelona.

Demongin, L. 2016. Identification guide to birds in the hand. - Beauregard-Vendon.

Dyrcz, A. 2020. Thick-billed Warbler (Arundinax aedon), version 1.0. - In Birds of the World (eds. del Hoyo, J., Elliott, A., Sargatal, J., Christie, D.E. \& de Juana, E.). Cornell Lab of Ornithology, Ithaca, NY, USA.

Elkins, N. 1988. Weather and bird behaviour. - Poyser, Calton.

Emlen, S.T. 1975. Migration: orientation and navigation. In Avian biology, Vol. V. (eds. Famer, D.S., King, J.R. \& Parkes, K.C.): 129-210. Academic Press, New York.

Erni, B., Liechti, F., Underhill, L.G. \& Bruderer, B. 2002. Wind and rain govern the intensity of nocturnal bird migration in central Europe-a log-linear regression analysis. - Ardea 90(1): 155-166.

Forstmeier, W., Bourski, O.V. \& Leisler, B. 2001. Habitat choice in Phylloscopus warblers: the role of morphology, phylogeny and competition. - Oecologia 128(4): 566-576.

Fransson, T. 1998. Patterns of migratory fuelling in Whitethroats Sylvia communis in relation to departure. — Journal of Avian Biology 29(4): 569-573.

Gauthreaux, S.A. 1982. The ecology and evolution of avian migration systems. - In Avian biology, Vol. VI. (eds. Farner, D.S. \& King, J.R.): 93. Academic Press, New York.

Gauthreaux, S.A. 1991. The flight behavior of migrating birds in changing wind fields: radar and visual analyses. - American Zoologist 31(1): 187-204.

Gill, R.E., Douglas, D.C., Handel, C.M., Tibbitts, T.L., Hufford, G. \& Piersma, T. 2014. Hemispheric scale wind selection facilitates Bar-tailed Godwit circummigration of the Pacific. — Animal Behaviour 90: 117130.

Glutz von Blotzheim, U.N. \& Bauer, K.M. 1991. Handbuch der Vögel Mitteleuropas. Bd. 12, Teil II. - AULA-
Verlag, Wiesbaden.

Gyurácz, J., Károssy, C. \& Csörgö, T. 1997. The autumn migration of Sedge Warblers in relation to weather conditions. - Weather 52(5): 149-154.

Gyurácz, J., Horváth, G., Csörgő, T., Bank, L. \& Palkó, S. 2003. Influence of macrosynoptic weather situation on the autumn migration of birds in Hungary. — Ring 25: 17-36.

Gyurácz, J. \& Csörgő, T. 2009. Common Chiffchaff (Phylloscopus collybita). - In Hungarian Bird Migration Atlas (eds. Csörgö, T., Karcza, Zs., Halmos, G., Magyar, G., Gyurácz, J., Szép, T., Bankovics, A., Schmidt, A. \& Schmidt, E.). 521-524. Kossuth Kiadó, Budapest. (In Hungarian with English summary)

Hammer, Ø., Harper, D.A. \& Ryan, P.D. 2001. PAST: Paleontological statistics software package for education and data analysis. - Palaeontologia Electronica 4(1): 9.

Howey, D. H. \& Bell, M. 1985. Pallas's Warbler and other migrants in Britain and Ireland in October 1982. Bitish Birds 78: 381-392.

Hüppop, O. \& Winkel, W. 2006. Climate change and timing of spring migration in the long-distance migrant Ficedula hypoleuca in central Europe: the role of spatially different temperature changes along migration routes. - Journal of Ornithology 147(2): 344-353.

Irving, L. 2012. Arctic life of birds and mammals: including man (Vol. 2). - Springer Science \& Business Media.

Kaiser, A. 1993. A new multi-category classification of subcutaneous fat deposits of songbirds. - Journal of Field Ornithology 64(2): 246-255.

Katti, M. \& Price, T.D. 2003. Latitudinal trends in body size among over-wintering leaf warblers (genus Phylloscopus). — Ecography 26(1): 69-79.

Kullberg, C., Fransson, T., Hedlund, J., Jonzén, N., Langvall, O., Nilsson, J. \& Bolmgren, K. 2015. Change in spring arrival of migratory birds under an era of climate change, Swedish data from the last 140 years. - Ambio 44(1): 69-77.

Lövei, G.L., Csörgő, T. \& Miklay, G. 2001. Capture efficiency of small birds by mist nets. - Ornis Hungarica 11: 19-25.

Lutgens, F.K. \& Tarbuck, E.J. 2001. The atmosphere: an introduction to meteorology. $8^{\text {th }}$ Edition - Prentice Hall.

Pennycuick, C.J. \& Battley PF. 2003. Burning the engine: a time-marching computation of fat and protein consumption in a $5420 \mathrm{~km}$ non-stop flight by Great Knots, Calidris tenuirostris. - Oikos 103(2): 323-332.

Piersma, T. \& Jukema, J. 1990. Budgeting the flight of a long-distance migrant: changes in nutrient reserve levels of bar-tailed godwits at successive spring staging sites. - Ardea 55(1-2): 315-337.

Price, T. 1991. Morphology and ecology of breeding warblers along an altitudinal gradient in Kashmir, India. — Journal of Animal Ecology 60(2): 643-664.

Pyle, P., Nur, N., Henderson, R.P. \& De Sante, D.F. 1993. The effects of weather and lunar cycle on nocturnal migration of landbirds at Southeast Farallon Island, 
California. — Condor 95(2): 343-361.

Richardson, W.J. 1978. Timing and amount of bird migration in relation to weather: a review. - Oikos 30(2): 224 272.

Richardson, W. 1990. Timing of bird migration in relation to weather: updated review. - In Bird migration (ed. Alerstam, T.): 78-101. Springer, Berlin, Heidelberg.

Ryder, J.P. 1971. Spring bird phenology at Karrak Lake, Northwest Territories. - Canadian Field-Naturalist 85: 181-183.

Schaub, M., Liechti, F. \& Jenni, L. 2004. Departure of migrating European Robins, Erithacus rubecula, from a stopover site in relation to wind and rain. - Animal Behaviour 67(2): 229-237.

Ścisłowska, M. \& Busse, P. 2005. Fat reserves and body mass in some passerines migrating in autumn through the southern Baltic coast. — Ring 27(1): 3-59.

Shamoun-Baranes, J. \& van Gasteren, H. 2011. Atmospheric conditions facilitate mass migration events across the North Sea. - Animal Behaviour 81(4): 691-704.

Svensson, L. 1992. Identification guide to European passerines. - Svensson, Stockholm.

Thorup, K., Tøttrup, A.P., Willemoes, M., Klaassen, R.H.G., Strandberg, R., Vega, M.L., Dasari, H.P., Araújo, M.B., Wikelsi, M. \& Rahbek, C. 2017. Resource tracking within and across continents in long-distance bird migrants. - Science Advances 3: e1601360.

Tøttrup, A.P., Rainio, K., Coppack, T., Lehikoinen, E., Rahbek, C. \& Thorup, K. 2010. Local temperature fine-tunes the timing of spring migration in birds. Integrative and Comparative Biology 50(3): 293-304.

Tøttrup, A.P., Pedersen, L., Onrubia, A., Klaassen, R.H. \& Thorup, K. 2017. Migration of Red-backed Shrikes from the Iberian Peninsula: optimal or sub-optimal detour? - Journal of Avian Biology 48(1): 149-154.

Tucker, V.A. 1974. Energetics of natural avian flight. Avian Energetics 15: 298-333.

Turcotte, Y. \& Desrochers, A. 2008. Forest fragmentation and body condition in wintering Black-capped Chickadees. — Canadian Journal of Zoology 86(6): 572-581.

Weber, T.P. \& Hedenström, A. 2000. Optimal stopover decisions under wind influence: the effects of correlated winds. - Journal of Theoretical Biology 205(1): 95104.

Wingfield, J.C., Hahn, T.P., Maney, D.L., Schoech, S.J., Wada, M. \& Morton, M.L. 2003. Effects of temperature on photoperiodically induced reproductive development, circulating plasma luteinizing hormone and thyroid hormones, body mass, fat deposition and molt in mountain White-crowned Sparrows, Zonotrichia leucophrys oriantha. — General and Comparative Endocrinology 131(2): 143-158.

Yong, D.L., Liu, Y., Low, B.W., Espanola, C.P., Choi, C.Y. \& Kawakami, K. 2015. Migratory songbirds in the East Asian-Australasian Flyway: a review from a conservation perspective. - Bird Conservation International 25(1): 1-37.

Yong, D.L., Heim, W., Chowdhury, S.U., Choi, C.Y., Ktitorov, P., Kulikova, O., Kondratyev, A., Round, P.D., Allen, D., Trainor, C., Gibson, L. \& Szabo, J.K. 2021. The state of migratory landbirds in the East Asian Flyway: Distributions, threats, and conservation needs. — Frontiers in Ecology and Evolution 9: 613172.

Yosef, R. \& Chernetsov, N. 2004. Stopover ecology of migratory Sedge Warblers (Acrocephalus schoenobaenus) at Eilat, Israel. — Ostrich 75(1-2): 52-56. 